\title{
Pengaruh Penerapan Sistem Manajemen Mutu Terhadap Budaya Kerja Karyawan
}

\section{Effect of Application of Quality Management System to Culture of Employees}

\author{
Erma Sulistyo Rini \\ STMIK STIKOM Bali \\ Jl. Raya Puputan No.86 Renon Denpasar Bali \\ erma@stikom-bali.ac.id
}

\begin{abstract}
Abstrak
Budaya kerja karyawan merupakan nilai-nilai dominan yang disebar luaskan didalam organisasi dan dijadikan acuan sebagai filosofi kerja karyawan atau merupakan sebuah sistem penyebaran kepercayaan dan nilai - nilai yang berkembang dalam suatu organisasi untuk mengarahkan prilaku para anggotanya [1] penelitian ini akan melihat apakah ada pengaruh signifikan penerapan sistem manajemen mutu ISO 9001:2008 untuk klausul 3.2 tentang Struktur Organisasi, klausul 6.2 tentang Sumber Daya Manusia dan Klausul 6.4 tentang Iklim Organisasi atau lingkungan kerja organisasi terhadap budaya kerja karyawan atau kinerja karyawan setelah STIKOM Bali menerapkan sistem manajemen mutu pada proses akademik. Studi tentang Sistem Manajemen Mutu yang dikaitkan dengan faktor budaya kerja karyawan menarik untuk dijadikan permasalahan, mengingat perusahaan yang direncanakan akan dijadikan obyek dalam penelitian ini sudah cukup lama mengimplementasikan sistem manajemen mutu dalam semua proses yang dijalankan selain itu setiap perusahaan memiliki karakteristik budaya yang berbeda satu dengan lainnya. sehingga diharapkan hasil dari penelitian ini dapat dijadikan bahan evaluasi bagi perusahaan jika ingin melakukan pengembangan program sistem manajemen mutu kedepannya sehingga setiap pengembangan dapat diikuti juga dengan peningkatan kompetensi karyawan
\end{abstract}

Kata kunci: ISO 9001:2008, Klausul 3.2 ; 6.2 \& 6.4, Budaya Kerja Karyawan

\begin{abstract}
Employee or organization culture is dominant values are disseminated for organization as a reference for employees working philosophy or belief system deployment and value. an organization to direct the behavior of its members [1] this resach will look at whether there is a significant effect of the implementation of quality management system ISO 9001: 2008 to clause 3.2 of the organizational Structure, clause 6.2 of the Human Resources and organizational. clause 6.4 of the organization or work environment for the culture of employee or the employee's performance after STIKOM Bali implement a quality management system in academic process. Study on the Quality Management System which is associated with employees' cultural factors interesting to be the problem, given that the company planned to be the object of this study is long enough to implement a quality management system in all processes. run besides each company has a different cultural characteristics of the other. so expect the results of this study can be used as material for the evaluation of the company if you want to develop a quality management system program in the future so that any development can be followed also by improving the competence of employees
\end{abstract}

Keywords: ISO 9001:2008, Klausul 3.2 ; $6.2 \& 6.4$, Employee culture

\section{PENDAHULUAN}

Budaya pasti terbentuk dalam organisasi seiring dengan berjalannya waktu dan dapat pula dirasakan manfaatnya dalam memberi kontribusi bagi efektivitas organisasi secara keseluruhan.

68 Jurnal Ilmiah SISFOTENIKA 
Budaya merupakan produk dari suatu komunitas, terdiri dari nilai-nilai yang diyakini dan dijalankan oleh individu dalam suatu organisasi / komunitas dan dijadikan perekat dan pedoman dalam kehidupan dan pemecahan dalam masalah. Budaya juga merupakan pembeda antara suatu komunitas dengan komunitas lainnya. [2] budaya organisasi adalah pola dasar yang diterima oleh organisasi untuk bertindak dan memecahkan masalah,membentuk karyawan yang mampu beradaptasi dengan lingkungan dan mempersatukan anggota-anggota organisasi. Untuk itu harus diajarkan kepada anggota termasuk anggota yang baru sebagai suatu cara yang benar dalam mengkaji, berpikir dan merasakan masalah yang dihadapi. Perubahan lingkungan organisasi yang semakin kompleks dan kompetitif, menuntut setiap organisasi dan perusahaan untuk bersikap lebih responsif agar sanggup bertahan dan terus berkembang. Hal ini dilakukan agar tetap mendapatkan kepercayaan (trust) dari pelanggan sehingga tetap bisa bersaing secara kompetitif dengan organisasi - organisasi yang lain. Banyak cara yang bisa digunakan untuk tetap bisa bersaing salah satunya adalah dengan mengimplementasikan sistem manajemen mutu yang merupakan sebuah sistem pengelolaan atau manajemen modern dimana dalam setiap proses yang dijalankan menggunakan alat bantu atau tools, dalam bentuk standarisasi yang diakui oleh dunia internasional. Sistem Manajemen Mutu memberikan jaminan mutu terhadap semua proses yang dijalankan, jika sebuah produk baik barang maupun jasa dari sisi proses sudah berkualitas maka output yang dihasilkan secara tidak langsung dapat dikatakan berkualitas atau bermutu. Hal ini disebabkan karena sistem manajemen mutu merupakan pendekatan yang dilakukan dari sisi proses, dimana pendekatan ini memiliki keterkaitan dengan pendekatan sistem dan pendekatan fakta yang berfungsi untuk mengukur keberhasilan program secara menyeluruh. Pendekatan proses ini tidak terlepas dari masukan (input) dan hasil proses (output). Pendekatan proses dalam SMM ISO 9001 memberikan dampak kepada organisasi terutama dalam kinerja.

Selain untuk mendukung perubahan organisasi sistem manajemen mutu juga diperlukan untuk dapat mendukung perubahan individu. Proses menyelaraskan perubahan organisasi dengan perubahan individu ini tidaklah mudah. Harus dimulai dari masing-masing anggota organisasi. Keberhasilan suatu organisasi dapat dilihat dari tercapainya tujuan organisasi tersebut dan kinerja karyawannya. Kinerja merupakan hasil kerja yang dicapai oleh seorang pegawai atau karyawan dalam melakukan tugas sesuai dengan tanggung jawab yang diberikan kepadanya. Mathis \& Jackson (2002) menyebutkan faktor yang mempengaruhi kinerja adalah kemampuan (ability) dan motivasi ( motivation ). Kuat lemahnya budaya suatu organisasi atau perusahaan sangat tergantung pada bagaimana para karyawan mengahayati dan mengamalkan nilai-nilai yang terkandung dalam budaya tersebut. Budaya yang kuat tentunya akan dapat menciptakan dan memperkuat komitmen karyawan terhadap organisasi. Dengan demikian karyawan akan tetap setia pada organisasinya dan tidak akan mudah terpengaruh oleh faktorfaktor lain, baik dari luar organisasi maupun dari dalam organisasi sendiri. Budaya perusahaan juga akhirnya akan berfungsi sebagai motivator bagi karyawan dalam melaksanakan pekerjaannya.[1]

Budaya kerja karyawan merupakan nilai-nilai dominan yang disebar luaskan didalam organisasi dan dijadikan acuan sebagai filosofi kerja karyawan atau merupakan sebuah sistem penyebaran kepercayaan dan nilai - nilai yang berkembang dalam suatu organisasi untuk mengarahkan prilaku para anggotanya [1] ), penelitian ini akan melihat apakah ada pengaruh terhadap budaya kerja karyawan setelah perusahaan menerapkan sistem manajemen mutu untuk setiap proses yang ada dan jika memiliki pengaruh seberapa signifikan pengaruh tersebut, untuk pengukuran ini direncanakan akan menggunakan 3 (tiga) dimenensi, pertama akan dilihat dari dimensi perencanaan sistem menajemen mutu berdasarkan persyaratan sertifikasi, kedua akan dilihat dari dimensi komitmen manajemen dalam mengimplementasikan sistem manajemen mutu dan yang ketiga akan dilihat dari dimensi penerapan prosedur. Studi tentang Sistem Manajemen Mutu yang dikaitkan dengan faktor budaya kerja karyawan menarik untuk dijadikan permasalahan, mengingat perusahaan yang direncanakan akan dijadikan obyek dalam 
penelitian ini sudah cukup lama mengimplementasikan sistem manajemen mutu dalam semua proses yang dijalankan selain itu setiap perusahaan memiliki karakteristik budaya yang berbeda satu dengan lainnya. sehingga diharapkan hasil dari penelitian ini dapat dijadikan bahan evaluasi bagi perusahaan jika ingin melakukan pengembangan program sistem manajemen mutu kedepannya sehingga setiap pengembangan dapat diikuti juga dengan peningkatan kompetensi karyawan

Berdasarkan uraian tersebut diatas, maka dapat ditarik perumusan permasalahan dalam penelitian ini sebagai berikut : Bagaimaan pengaruh penerapan sistem manajemen mutu terhadap budaya kerja karyawan ? Berapa besar pengaruh penerapan sistem manajemen mutu terhadap budaya kerja karyawan?

Sistem manajemen mutu adalah suatu kegiatan sistemik dan terpadu oleh satuan atau program pendidikan, penelenggara satuan atau program pendidikan, pemerintah daerah, pemerintah dan masyarakat untuk menaikan tingkat kecerdasan kehidupan bangsa melalui pendidikan. [3]. Dengan kata lain penjaminan mutu secara umum adalah proses penetapan dan pemenuhan standar mutu pengelolaan secara konsisten dan berkelanjutan, sehingga konsumen, produsen dan pihak lain yang berkepentingan memperoleh kepuasan. Quality Assurance in Higher Education is A systematic management and assessment procedures adopted by a higher education institution or system to monitor performance and to ensure achievement of quality outputs or improved quality. [4]

Penjaminan mutu meliputi: penjaminan mutu internal dan penjaminan mutu eksternal. Penjaminan mutu internal (internal quality Assurance), bentuknya berupa evaluasi diri yang dilakukan oleh program studi atau institusi perguruan tinggi. Tujuannya untuk memperbaiki kinerja dan memberi penjaminan mutu internal, khususnya kepada dosen, peneliti, karyawan, dan mahasiswa.

Budaya pasti terbentuk dalam organisasi seiring dengan berjalannya waktu dan dapat pula dirasakan manfaatnya dalam memberi kontribusi bagi efektivitas organisasi secra keseluruhan.Budaya merupakan produk dari suatu komunitas, terdiri dari nilai-nilai yang diyakini dan dijalankan oleh individu dalam suatu organisasi / komunitas dan dijadikan perekat dan pedoman dalam kehidupan dan pemecahan dalam masalah. Budaya juga merupakan pembeda antara suatu komunitas dengan komunitas lainnya.

udaya organisasi merupakan suatu sistem makna bersama yang disepakati dan dijalankan oleh anggota organisasi. Budaya organisasi baik yang positif atau negatif lambat laun akan mempengaruhi perilaku yang pada akhirnya berpengaruh pada produktivitas dan pencapaian tujuan organisasi. Kesesuaian antara individu dengan budaya organisasi dimana seseorang tersebut bekerja, akan menimbulkan kepuasan kerja, komitmen kerja dan akan mendorong individu untuk bertahan pada suatu perusahaan tersebut dalam jangka panjang.

Budaya organisasi adalah pegangan bagi karyawan perusahaan dalam berperilaku yang menjadi pedoman dalam berinteraksi dengan sesama rekan kerja, dan menjadi pedoman dalam pengambilan keputusan. Kepuasan kerja akan didapatkan jika harapan-harapn dari pekerjaannya dapat dipenuhi. Dengan mengambil pemikiran tersebut, dimungkinkan bahwa budaya organisasi dapat memberikan pengaruh positif terhadap kepuasan kerja karyawan. Budaya organisasi diyakini akan mempengaruhi sikap individu menyangkut keluaran-keluaran seperti komitmen, motivasi moral, dan kepuasan kerja.

Karyawan merupakan pelaku yang menunjang tercapainya tujuan.[5] Untuk mengembangkan sikap-sikap positif yang akan mengarahkan karyawan pada pencapaian tujuan perusahaan, maka motivasi harus ditingkatkan,dalam hal ini baik motivasi eksternal maupun motivasi internal.Motivasi merupakan dorongan, upaya dan keinginan yang ada pada diri manusia yang akan mengarahkan perilaku untuk melakukan tugas atau pekerjaan dengan baik, sedangkan kepuasan merupakan sikap yang menunjukkan adanya kesesuaian antara harapan dan hasil yang didapatkan.

Ada dua kemungkinan yang terjadi apabila kepuasan kerja seorang karyawan tinggi 
terhadap pekerjaannya,yaitu kinerjanya akan menjadi lebih produktif atau stagnan. Namun sebaliknya apabila pekerjaan dianggap kurang menyenangkan akan muncul juga dua kemungkinan yaitu karyawan tetap bersikap stagnan dan cenderung menurun produktivitasnya,atau bersikap tidak peduli pada produktivitas kerjanya. Berdasarkan gambaran kemungkinan diatas bisa diketahui bahwa kepuasan kerja memegang pengaruh penting baik bagi individu maupun organisasi. [1] menyatakan bahwa kepuasan kerja mempunyai peran untuk penggunaan sumber daya manusia yang lenih efisien, menghindari kemungkinan membangun kekuatan kerja yang lebih stabil, serta untuk mencapai produktivitas dan kualitas standar yang lebih baik.

Sumber daya manusia memiliki peran penting diantara faktor-faktor yang lain dalam organisasi perusahan. Hal tersebut menuntut perusahaan perlu memperhatikan kinerjanya. Usaha peningkatan kinerja karyawan melalui memberikan pendidikan, pelatihan dan pengembangan baik untuk kebutuhan jangka pendek maupun jangka panjang selalu dilakukan perusahaan. Beberapa uraian tentang kinerja dalam Rivai (2005) adalah sebagai berikut: 1) Kinerja merujuk pada tingkat keberhasilan dalam melaksanakan tugas serta kemampuan untuk mencapai tujuan yang telah ditetapkan, 2) Kinerja dinyatakan baik dan sukses jika tujuan yang diinginkan dapat dicapai dengan baik dan kinerja tidak berdiri tetapi dipengaruhi tiga factor kemampuan, keinginan dan lingkungan [6]. Kinerja sebagai fungsi interaksi antara kemampuan atau ability (A), motivasi atau motivation (M), dan kesempatan atau Opportunity (O) yaitu: Kinerja $=\mathrm{f}(\mathrm{A} \times \mathrm{M} \times \mathrm{O})$, artinya kinerja merupakan fungsi dari kemampuan, motivasi dan kesempatan [6]. Dari pendapat diatas maka dapat di simpulkan Performance atau kinerja adalah hasil kerja yang dapat dicapai seseorang atau kelompok orang dalam suatu perusahaan sesuai dengan wewenang dan tanggung jawab masing-masing dalam upaya pencapaian tujuan perusahaan secara legal, tidak melanggar hukum, tidak bertentangan dengan etika dan dipengaruhi oleh kemampuan, keinginan, lingkungan, kesempatan.

Dalam konsep manajemen, manusia sebagai sumber daya dalam perusahaan/instansi diharapkan mampu untuk memanfaatkan dan meningkatkan tenaga sepenuhnya atau seoptimal mungkin untuk meningkatkan produktifitas yang diikuti oleh terciptanya hubungan kerja yang bermutu dengan konotasi yang menyenangkan, penuh tenggang rasa dan saling membangun. Memanfaatkan sumber daya manusia terkandung pengertian pembinaan struktur organisasi dan pengembangan mutu tenaga kerja baik secara aktual maupun potensial. Kinerja tidak hanya merupakan produktifitas karena kinerja menyangkut perilaku alami yang dimiliki seorang untuk bebas melakukan tindakan sesuai keinginannya, perilaku bebas untuk bertindak ini tetap tidak bisa dilepaskan darisyarat-syarat formal peran seorang karyawan untuk meningkatkan fungsi efektif suatu organisasi.

Penerapan SMM ISO menurut Brown and van der Wiele, (1998); Mears and Voehl, (1995); Meyer and Allen, (1997); Zink, (1994) dalam [2] terdiri dari tiga framework yakni: (1) Perencanaan sertifikasi ISO 9001, (2) Komitmen organisasi, dan (3) Penerapan prosedur. Budaya kualitas merupakan pola nilai, keyakinan, dan harapan yang tertanam dan berkembang dikalangan anggota organisasi mengenai perkejaannya untuk menghasilkan produk atau jasa yang berkualitas. (Hardjosoedarmo, 1999).

Kinerja karyawan dapat dilihat dari kinerja yang berpengaruh signifikan hanya pada kinerja operasional sedangkan pada kinerja bisnis pengaruhnya sangat lemah. Adapun kinerja menurut Russel (1993): a) Kualitas kerja, b) Kuantitas kerja, c) Waktu kerja, dan d) Efektifitas kerja.Penilaian kinerja bertujuan untuk menilai seberapa baik karyawan telah melaksanakan pekerjaannya dan apa yang harus mereka lakukan untuk menjadi lebih baik di masa mendatang. Ini dilaksanakan dengan merujuk pada isi pekerjaan yang mereka lakukan dan apa yang mereka harapkan untuk mencapai setiap aspek dari pekerjaan mereka. Isi dari suatu pekerjaan merupakan dasar tetap untuk perumusan sasaran yang akan dicapai dari suatu tugas utama yang dapat dirumuskan sebagai target kuantitas, standar kinerja suatu tugas atau proyek tertentu untuk diselesaikan [1] 


\section{METODE PENELITIAN}

Bab ini menjelaskan mengenai tempat dan waktu penelitian, metode pengumpulan data, dan teknik analisis data. Penelitian dilakukan pada salah satu perusahaan yang telah mengimplemntasikan sistem manajemen mutu sedangkan yang menjadi obyek dalam penelitian ini adalah karyawan yang terlibat pada proses utama penerapan sistem manajemen mutu. Waktu penelitian direncanakan selama 4 (empat) bulan dimulai dari bulan Juli sampai dengan Oktober 2014. Teknik pengumpulan data pada penelitian ini menggunakan : (1) Studi Literatur yaitu metode pengumpulan data dan informasi dari sumber sekunder dengan mempelajari dan membaca literatur yang terkait sistem manajemen mutu, budaya organisasi dan kinerja karyawan baik yang berasal dari buku dan jurnal (2) Angket atau kuisioner yaitu metode pengumpulan data dan informasi dari sumber primer dengan melakukan penyebaran angket atau kuisioner kepada responden untuk selanjutnya mengolah data hasil kuisioner. (3) Observasi yaitu metode pengumpulan data dan informasi dengan melakukan pengamatan secara langsung terhadap penerapan sistem manajemen mutu pada proses serta mengamati budaya kerja karyawan pada obyek penelitian

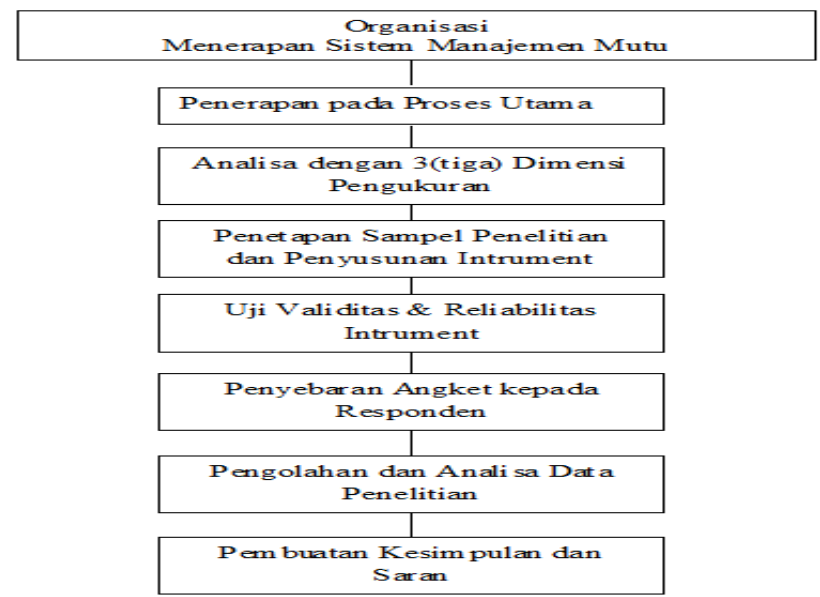

Gambar 1. Tahapan Kegiatan Penelitian

Populasi dalam penelitian ini adalah karyawan yang terlibat dalam proses utama penerapan sistem manajemen mutu perusahaan mulai dari level top manajemen sampai dengan level karyawan secara umum populasi dimaksudkan sebagian wilayah generalisasi yang terdiri dari obyek/subyek yang mempunyai kualitas dan karakteristik tertentu. Sampel secara umum menjelaskan mengenai sebagian dari jumlah dan karakteristik yang dimiliki oleh populasi tersebut. Pada penelitian ini, teknik penarikan sampel yang digunakan adalah random Sampling yaitu cara pengambilan sampel secara acak dari populasi yang mempunyai anggota/unsur tidak homogen dan berstrata secara proporsional[7], penentuan jumlah sampel penelitian yang harus diambil dari populasi berstrata dengan tingkat kesalahan $10 \%$.

Variabel-variabel yang akan digunakan dalam penelitian ini dibagi atas:

1. Variabel terikat (dependent), merupakan variabel yang nilainya dipengaruhi oleh variabel bebas. Dalam penelitian ini yang menjadi variabel terikat adalah yaitu Budaya Kerja Karyawan (Y).

2. Variabel bebas (independent) merupakan variabel yang nilainya mempengaruhi variabel terikat . dalam penelitian ini yang menjadi variabel bebas adalah penerapan sistem manajemen mutu ISO 9001:2008 khusunya klausul 3.2 untuk struktur organisasi, klausul 6.2 untuk sumber daya manusia dan klausul 6.4 tentang lingkugan kerja atau iklim organisasi yang terdiri dari variabel sumber daya manusia (X1) memiliki sembilan item atau intrument/pernyataan seperti keahlian, pendidikan \& pelatihan serta 
pengalaman kerja. Variabel iklim organisasi (X2) memiliki dua item atau intrument/pernyataan yaitu kondisi lingkungan kerja, hubungan dan komunikasi serta jaminan pengembangan karir karyawan. Variabel struktur organisasi (X3) memiliki empat item atau intrument/pernyataan seperti pembagian tugas dan tanggung jawab, departemenlisasi, dan koordinasi antar anggota dan unit-unit dalam organisasi

Sesuai dengan rumusan masalah penelitian ini menggunakan instrumen penelitian dalam bentuk angket untuk memperoleh data-data yang terkait dengan penerapan sistem Manajemen Mutu ISO 9001:2008 angket yang digunakan didesain berdasarkan model skala likert yang berisi sejumlah pernyataan yang menyatakan objek yang hendak diungkap, penskoran atas angket menggunakan skala likert dalam penelitian ini merujuk pada lima alternatif jawaban, sebagaimana terlihat dibawah ini yaitu: Sangat Berpengaruh $=4$, Berpengaruh $=3$, Kurang Berpengaruh $=2$, Tidak Berpengaruh $=1$. Setelah instrumen dikembangkan maka perlu dilakukan pengujian instrumen yang meliputi uji validitas, dan reliabilitas. Penelitian ini merupakan penelitian Ex Post Facto yaitu penelitian yang dilakukan untuk meneliti peristiwa yang telah terjadi yang kemudian merunut ke belakang untuk mengetahui faktor-faktor yang dapat menimbulkan kejadian tersebut. [7]. Model desain penelitian ini adalah model kausal korelasional yaitu suatu model hubungan antara variable terikat dan variable bebas. Variabel terikat dalam penelitian ini adalah Budaya Kerja Karyawan sedangkan variable bebasnya adalah penerapan sistem manajemen mutu ISO 9001:2008

\begin{tabular}{|c|c|c|}
\hline $\begin{array}{c}\text { Penerapan Sistem Manajemen } \\
\text { Mutu ISO 9001-2008 }\end{array}$ & Budaya Kerja Karyawan \\
\cline { 3 - 3 }
\end{tabular}

Hipotesa penelitian adalah:

Ho : Terdapat pengaruh penerapan Sistem Manajemen Mutu ISO $9001: 2008$

Terhadap Budaya Kerja Karyawan

H1 : Tidak terdapat pengaruh penerapan Sistem manajemen mutu ISO 9001:2008 terhadap budaya kerja karyawan

Teknik analisis data yang akan digunakan untuk mengolah data dalam penelitian ini adalah menggunakan analisis regresi dan sebelumnya dilakukan uji validitas dan reabilitas terhadap instrument yang digunakan dalam penelitian. Analisis regresi, digunakan untuk mengukur seberapa jauh pengaruh penerapan sistem manajemen mutu ISO 9001:2008 pada proses akademik khusunya pada klausul 6.2 terkait sumber daya manusia, klausul 6,4 tentang lingkungan kerja atau iklim organisasi dan klausul 3.2 tentang struktur organisasi terhadap budaya kerja karyawan atau kinerja pegawai. model regresi sebagai berikut:

Keterangan:

$$
\mathrm{Y}=\mathrm{a}+b 1 X 1+b 2 X 2+b 3 X 3
$$

$\mathrm{Y}=$ Kinerja Karyawan

$\mathrm{X} 1=$ Sumber daya manusia

$\mathrm{X} 2$ = Iklim Organisasi

X3 =Struktur Organisasi

\section{HASIL DAN PEMBAHASAN}

Data yang diperlukan dikumpulkan melalui penyebaran angket yang disebarkan kepada responden penelitian yang terdiri dari 2 (dua) bagian dimana bagian pertama merupakan identitas responden dengan mengajukan 6 (enam) buah pertanyaan yang berhubungan dengan nama unit/bagian, jabatan, jenis kelamin, usia, pendidikan terakhir dan peranan di sistem manajemen mutu STIKOM Bali untuk mengetahui tingkat relevansi responden dengan tema atau topik yang diangkat oleh penulis, sedangkan pada bagian kedua merupakan pertanyaan tentang pengaruh penerapan sistem manajemen mutu pada proses akademik terhadap budaya kerja karyawan di Sekolah Tinggi Manajemen Informatika dan Teknik Komputer ( STMIK ) STIKOM Bali 
Berikut disajikan hasil atau data - data yang diperolah dari penyebaran angket kepada 15 (lima belas) orang responden yang dijadikan sampel dalam penelitian ini dapat dilihat pada tabel dibawah ini :

Tabel 1. Karakteristik Responden Penelitian di STIKOM Bali

\begin{tabular}{|c|c|c|c|c|}
\hline No & Karakeristik & Jawaban & Frekuensi & Prosentase \% \\
\hline \multirow[t]{2}{*}{1} & \multirow[t]{2}{*}{ Jenis Kelamin } & Laki - Laki & 5 & $33 \%$ \\
\hline & & Perempuan & 10 & $67 \%$ \\
\hline \multirow[t]{3}{*}{2} & \multirow[t]{3}{*}{ Usia / Umur ( Tahun ) } & $27-30$ & 8 & $53 \%$ \\
\hline & & $30-35$ & 6 & $40 \%$ \\
\hline & & 35 - keatas & 1 & $7 \%$ \\
\hline \multirow{6}{*}{3} & \multirow{6}{*}{$\begin{array}{l}\text { Unit \& Jabatan serta Peranan } \\
\text { di Sistem Manajemen Mutu } \\
\text { STIKOM Bali }\end{array}$} & Puket 1 & 1 & $8 \%$ \\
\hline & & Ka. Prodi & 3 & $23 \%$ \\
\hline & & Admin Akademik & 3 & $8 \%$ \\
\hline & & MR & 1 & $8 \%$ \\
\hline & & ISO Sekretariat & 1 & $8 \%$ \\
\hline & & Wakil ISO Sekrt. & 6 & $46 \%$ \\
\hline \multirow[t]{3}{*}{4.} & \multirow[t]{3}{*}{ Pendidikan Terakhir } & Diploma & 2 & $13 \%$ \\
\hline & & S1 & 6 & $40 \%$ \\
\hline & & S2 & 7 & $47 \%$ \\
\hline
\end{tabular}

Pada tabel 1 dapat disimpulkan bahwa dari 15 orang responden yang dijadikan sampel $33 \%$ berjenis kelamin laki - laki dan $67 \%$ berjenis kelamim perempuan dan jika dilihat dari karakteristik usia atau umur $53 \%$ berusia antara 27sampai dengan 30 tahun, $40 \%$ berusia antara 30 sampai dengan 35 tahun dan $7 \%$ untuk responden yang berusia 35 Tahun keatas sedangkan jika dilihat dari Unit, Jabatan dan Peranan responden dalam sistem manajemen mutu untuk proses akademik pada STIKOM Bali sebagai berikut $8 \%$ dari Pembantu Ketua I Bidang Akademik yang memiliki peran sebagai penanggung jawab proses akademik, 23\% dari Ketua Program Studi STIKOM Bali yang terdiri dari Sistem Komputer, Sistem Informasi dan Manajemen Informatika , 8\% dari Administrasi Akademik sebagai pelaksana setiap proses akademik, 8\% dari Management Representative (MR) sebagai penanggung jawab sistem manajemen mutu di STIKOM Bali, 8\% dari ISO Sekretariat sebagai penanggung jawab dokumentasi mutu STIKOM Bali dan $46 \%$ dari Wakil ISO Sekretariat yang bertanggung jawab untuk menjaga semua bentuk rekaman dan dokumen pada proses akademik STIKOM Bali. Dilihat dari latar belakang pendidikan terdapat 13\% karyawan berpendidikan diploma, $40 \%$ karyawan berpendidikan sarjana atau S1 dan 47\% karyawan berpendidikan megister atau S2

Uji validitas dilakukan untuk memastikan bahwa seluruh item instrument yang digunakan dalam penelitian ini memiliki konsistensi untukmengukur aspek yang sama dalam kuesioner. Pengujian validitas dilakukan dengan menggunakan korelasi PearsonProduct Moment. Hasil korelasi (r)Pearson digunakan untuk mendeteksi validitas dari masing-masing item instrument. Item instrument dinyatakan valid apabila nilai (r) hitung lebih besar dari nilai (r) tabel, sesuai dengan derajat kebebasan dan signifikansinya.Secara keseluruhan hasil pengujian validitas masing-masing variabel dapat dilihat pada Tabel 2 berikut ini.

Tabel 2. Hasil Uji Validitas Intrument Penelitian

\begin{tabular}{|c|c|c|c|c|}
\hline Variabel & Item & $\begin{array}{l}\text { Koefesien } \\
\text { Korelasi } \\
\end{array}$ & Sig & Keterangan \\
\hline \multirow{9}{*}{ Sumber Daya Manusia (X1) } & $\mathrm{X} 1.1$ & 0,790 & 0,000 & Valid \\
\hline & $\mathrm{X} 1.2$ & 0,731 & 0,000 & Valid \\
\hline & $\mathrm{X} 1.3$ & 0,818 & 0,000 & Valid \\
\hline & $\mathrm{X} 1.4$ & 0,841 & 0,000 & Valid \\
\hline & $\mathrm{X} 1.5$ & 0,728 & 0,000 & Valid \\
\hline & $\mathrm{X} 1.6$ & 0,706 & 0,000 & Valid \\
\hline & $\mathrm{X} 1.7$ & 0,818 & 0,000 & Valid \\
\hline & $\mathrm{X} 1.8$ & 0,902 & 0,000 & Valid \\
\hline & $\mathrm{X} 1.9$ & 0,763 & 0,000 & Valid \\
\hline \multirow[t]{2}{*}{ Iklim Organisasi (X2) } & $\mathrm{X} 2.1$ & 0,824 & 0,000 & Valid \\
\hline & $\mathrm{X} 2.2$ & 0,797 & 0,000 & Valid \\
\hline
\end{tabular}




\begin{tabular}{lllll}
\hline Struktur Organisasi (X3) & X3.1 & 0,821 & 0,000 & Valid \\
\cline { 2 - 5 } & X3.2 & 0,829 & 0,000 & Valid \\
\cline { 2 - 5 } & X3.3 & 0,858 & 0,000 & Valid \\
\cline { 2 - 5 } & X3.4 & 0,840 & 0,000 & Valid \\
\hline
\end{tabular}

Berdasarkan tabel tersebut diatas, menunjukan bahwa variabel sumber daya manusia (X1) yang terdiri dari 9 ( Sembilan) instrument/item pernyataan,dari X1.1 s/d X1.9 memiliki koefesien korelasi $0.731-0,902$ lebih besar dari pada nilai r-tabel 0,514 dengan tingkat Sig. $5 \%$ atau nilai untuk masing-masing variabel lebih kecil daripada $\alpha=0,05$ sehingga instrument yang digunakan untuk item variabel sumber daya manusia dari X1.1 - X1.9 dapat dinyatakan valid dan dapat diikutsertakan dalam analisa selanjutnya. Pada item variabel iklim organisasi (X2) untuk kedua instrument yaitu X2.1 dan X2.2 serta item variabel struktur organisasi (X3) untuk keempat instrument yaitu X3.1 - X3.4 memiliki koefesien korelasi mulai dari 0,797 0,858 dimana nilai tersebut lebih besar daripada r-tabel 0,514 dengan tingkat Sig. 5\% atau nilai untuk masing-masing variabel lebih kecil daripada $\alpha=0,05$ sehingga instrument yang digunakan untuk item variabel iklim organisasi dan struktur organisasi dapat dinyatakan valid dan dapat diikutsertakan dalam analisa selanjutnya.

Uji Reliabilitas menunjuk pada satu pengertian bahwa sesuatu instrument cukup dapat dipercaya untuk digunakan sebagai alat pengumpul data karena instrumen tersebut sudah cukup baik (Arikunto, 2006:178). Uji reliabilitas dilakukan dengan menggunakan koefisien alpha cronbach, dengan taraf nyata sebesar 5\%. Kriteria dalam uji reliabilitas menggunakan koefisien alpha cronbach adalah jika koefisien korelasi lebih besar dari nilai kritis $(>0,60)$, maka instrumen tersebut dinyatakan reliabel. Hasil uji reliabilitas seluruh variabel ditunjukkan dalam Tabel berikut

Tabel 3. Hasil Uji Reliabelitas Intrument Penelitian

\begin{tabular}{lll}
\hline Variabel & Koefesien Alpha Cronbach & Kesimpulan \\
\hline $\mathrm{X} 1$ & 0,890 & Reliabel \\
\hline $\mathrm{X} 2$ & 0,880 & Reliabel \\
\hline $\mathrm{X} 3$ & 0,912 & Reliabel \\
\hline $\mathrm{Y}$ & 0,862 & Reliabel \\
\hline
\end{tabular}

Dari tabel hasil uji diatas menunjukan bahwa hasil perhitungan atau nilai dari koefesien Alpha Cronbach variabel X1 sumber daya manuasi, variabel X2 Iklim Organisasi dan X3 Struktur Organisasi serta variabel Y untuk implementasi penjaminan mutu pada proses akademik dengan instrument kinerja karyawan lebih besar dari 0,6 hal ini menunjukkan bahwa hasil perhitungan koefisien Alpha Cronbach variabel Sumber Daya Manusia (X1), Iklim Organisasi (X2), dan Struktur Organisasi (X3) serta penerapan sistem manajemen mutu pada proses akademik dengan instrument yang digunakan adalah kinerja karyawan ( $\mathrm{Y}$ ) dengan demikian dapat disimpulkan bahwa indikator yang digunakan untuk mengukur variabel tersebut adalah reliabel (handal).

- Keahlian yang digunakan sebagai indikator pengukuran yaitu Standar pelaksanaan tugas artinya dalam penyelesaian pekerjaan sesuai dengan apa yang telah ditetapkan dalam prosedur manual organisasi, Ketepatan waktu artinya ketepatan dan kecepatan menyelesaikan pekerjaan dibandingkan standar waktu yang telah ditetapkan , Kemampuan memotivasi diri dan orang lain dalam pekerjaan; Kemampuan menjalankan kerjasama dengan pegawai lainnya; Kecakapan dalam menuangkan gagasan untuk kemajuan pekerjaan

- Pendidikan dan Pelatihan indikator yang digunakan untuk pengukuran adalah pelatihan formal dan informal yang telah diikuti

- Pengalaman Kerja indikator yang digunakan adalah masa kerja pegawai atau pengalaman kerja dalam hitungan tahun serta jenis pekerjaan yang pernah ditangani atau dihandle

Tabel 4. Distribui Frekuensi Jawaban Responden Untuk Klausul 6.2

Variabel Sumber Daya Manusia

\begin{tabular}{lllll}
\hline Item Variabel & Jumlah Responden & & \\
\hline Sumber Daya Manusia & 1 & 2 & 3 & 4 \\
\hline
\end{tabular}


Pengaruh Penerapan Sistem Manajemen Mutu ...

\begin{tabular}{lllllllll}
\hline Keahlian & $\mathrm{F}$ & $\%$ & $\mathrm{~F}$ & $\%$ & $\mathrm{~F}$ & $\%$ & $\mathrm{~F}$ & $\%$ \\
\hline $\mathrm{X} 1.1$ & - & - & 1 & 2,5 & 26 & 65 & 13 & 32,5 \\
\hline $\mathrm{X} 1.2$ & - & - & - & - & 31 & 77,5 & 9 & 22,5 \\
\hline $\mathrm{X} 1.3$ & - & - & 1 & 2,5 & 25 & 62,5 & 14 & 35 \\
\hline $\mathrm{X} 1.4$ & - & - & - & - & 24 & 60 & 16 & 40 \\
\hline X1.5 & - & - & 1 & 2,5 & 17 & 42,5 & 22 & 55 \\
\hline X1.6 & - & - & - & - & 29 & 72,5 & 11 & 27,5 \\
\hline Pendidikan dan Pelatihan $(X 1.7)$ & - & - & 4 & 10 & 22 & 55 & 14 & 35 \\
\hline Pengalaman kerja & & & & & & & & \\
\hline X1.8 & 1 & 2,5 & 5 & 12.5 & 29 & 72,5 & 5 & 12,5 \\
\hline X1.9 & - & - & 5 & 12.5 & 27 & 67,5 & 6 & 15 \\
\hline
\end{tabular}

Pada item variabel pertama instrument keahlian yang menyatakan kurang berpengaruh sebanyak $2,5 \%$, yang menyatakan berpengaruh sebanyak $65 \%$ yang menyatakan sangat berpengaruh sebanyak $32,5 \%$. Untuk item kedua instrument keahlian yang menyatakan berpengaruh sebanyak $77,5 \%$ dan yang menyatakan sangat berpengaruh sebanyak $22,5 \%$. Untuk item ketiga instrument keahlian, yang menyatakan tidak berpengaruh sebanyak $2.5 \%$, yang menyatakan berpengaruh sebanyak $62,5 \%$, dan yang menyatakan sangat berpengaruh sebanyak 35\%. Untuk item keempat instrument keahlian yang menyatakan berpengaruh sebanyak $60 \%$, yang menyatakan sangat berpengaruh sebanyak $40 \%$. Untuk item kelima instrument keahlian, yang menyatakan tidak berpengaruh sebanyak 2,5\%, yang menyatakan berpengaruh sebanyak $42,5 \%$, dan yang menyatakan sangat berpengaruh sebanyak $55 \%$. Untuk item keenam instrument keahlian yang menyatakan berpengaruh sebanyak $72,5 \%$, yang menyatakan sangat berpengaruh sebanyak $27,5 \%$. Untuk item ketujuh instrument pendidikan dan pelatihan yang menyatakan tidak berpengaruh $10 \%$, yang menyatakan berpengaruh $55 \%$ dan yang menyatakan sangat berpengaruh $35 \%$. Pada item kedelapan instrument pengalaman kerja yang menyatakan sangat tidak berpengaruh sebanyak 2,5\%, yang menyatakan tidak berpengaruh $12,5 \%$, yang menyatakan berpengaruh sebanyak $72,5 \%$ dan yang menyatakan sangat berpengaruh sebanyak $12,5 \%$. Pada item kesembilan instrument pengalaman kerja yang menyatakan tidak berpengaruh sebanyak $12,5 \%$, yang menyatakan berpengaruh sebanyak 67,5 dan yang menyatakan sangat berpengaruh sebanyak $15 \%$. Hasil analisis tersebut menunjukkan bahwa karyawan sekolah tinggi manajemen informatika dan teknik computer (STMIK) STIKOM Bali telah memahami peran dan tanggung jawab terhadap pekerjaan sesuai dengan kompetensi yang dimiliki, serta mampu memanfaatkan pelatihan yang diberikan organisasi dalam meningkatkan keterampilan dan sikap kerja dalam pekerjaan. Sehingga hal ini berpengaruh ketika institusi mengimplementasikan sistem manajemen mutu pada proses akademik

Intrument yang digunakan dalam variabel iklim organisasi berdasarkan definisi operasional variable terdiri dari :

- Kondisi lingkungan kerja yang menunjang seperti rekan kerja, atasan dan bawahan dengan terciptanya hubungan dan komunikasi yang baik antar karyawan terbina sehingga suasana kerja terasa menyenangkan, dan karyawan tidak menemui kesulitan untuk berkomunikasi dengan sesama karyawan satu unit kerja disamping itu karyawan diberikan kesempatan dalam melakukan pengembangan diri melalui pelatihan, seminar, dan pendidikan .

Tabel 5. Distrubusi Frekuensi Jawaban Responden untuk Klausul 6.4

Variabel Iklim Organisasi atau Lingkungan Organisasi

\begin{tabular}{lllllllll}
\hline Item Variabel & \multicolumn{7}{l}{ Jumlah Responden } & \multicolumn{7}{l}{} \\
\hline Iklim Organisasi & $\mathbf{1}$ & $\mathbf{2}$ & $\mathbf{3}$ & $\mathbf{4}$ & \\
\hline Hubungan kerja dan Komunikasi & $\mathrm{F}$ & $\%$ & $\mathrm{~F}$ & $\%$ & $\mathrm{~F}$ & $\%$ & $\mathrm{~F}$ & $\%$ \\
\hline X2.1 & - & - & 3 & 7,5 & 25 & 62,5 & 12 & 30 \\
\hline Pengembangan Karir & & & & & & & & \\
\hline X2.2 & 1 & 2,5 & 1 & 2,5 & 21 & 52,5 & 17 & 42,5 \\
\hline
\end{tabular}

Pada item pertama variable iklim organisasi instrument hubungan kerja dan komunikasi yang menyatakan tidak berpengaruh sebanyak 7,5\%, yang menyatakan berpengaruh sebanyak $62,5 \%$ dan yang menyatakan sangat berpengaruh sebanyak $30 \%$. Sedangkan pada item kedua 
instrument pengembangan karir yang menyatakan sangat tidak berpengaruh 2,5\%, yang menyatakan tidak berpengaruh sebanyak $2,5 \%$, yang menyatakan berpengaruh sebanyak $52,5 \%$ dan yang menyatakan sangat berpengaruh sebanyak $42,5 \%$ sehingga dapat disimpulkan bahwa Sekolah Tinggi Manajemen Informatika dan Teknik Komputer (STMIK) STIKOM Bali memiliki iklim organisasi yang dapat menunjang pekerjaan dan budaya kerja karyawan serta memiliki sistem pengelolaan karyawan yang baik sehingga dapat menunjang karir dari karyawan

- Struktur Organisasi yang dapat dipengaruhi oleh penerapan sistem manajemen mutu meliputi kesesuaian bakat dan minat karyawan dengan pekerjaan yang ditangani, kecocokan dalam pengelompokan pekerjaan, ketidaksesuaian informasi antar unit yang mengakibatkan konflik, jenjang atau tingkat kewenangan dengan pertanggung jawaban, kordinasi dan peranan unit kerja dan integritas karyawan .

Tabel 6. Distribusi Frekuensi Jawaban Responden Untuk Klausul 3.2

\section{Variabel Struktur Organisasi}

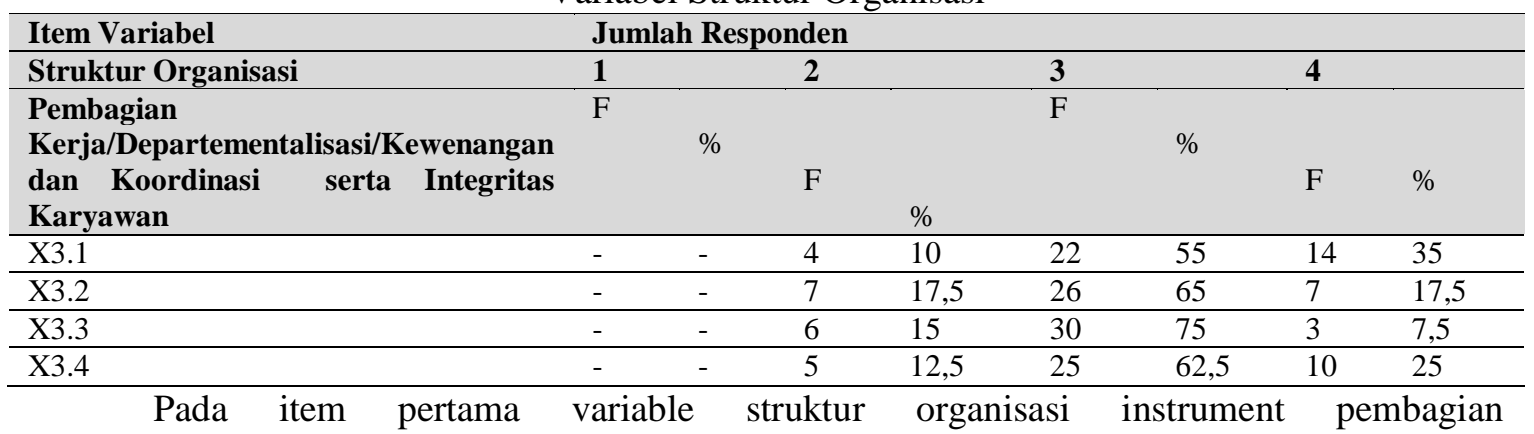

kerja/departementalisasi/kewenangan dan koordinasi serta integritas karyawan yang menyatakan kurang berpengaruh sebesar 10\%, yang menyatakan berpengaruh sebesar 55\% dan yang menyatakan sangat berpengaruh sebanyak 35\%, selanjutnya pda item kedua instrument yang sama yang menyatkan kurang berpengaruh sebanyak $17,5 \%$, yang menyatakan berpengaruh sebanyak 65\% dan yang menyatakan sangat berpengaruh sebanyak 17,5\%, selanjutnya untuk item ketiga instrument yang sama yang menyatakan kurang berpengaruh sebanyak $15 \%$, yang menyatakan berpengaruh sebanyak $75 \%$ dan yang menyatakan sangat berpengaruh sebanyak $7,5 \%$ dan dari item keempat pada instrument yang sama yang menyatakan kurang berpengaruh sebanyak $12,5 \%$, yang menyatakan berpengaruh sebanyak $62,5 \%$ serta yang menyatakan sangat berpengaruh sebanyak $25 \%$. Dari uraian tersebut dapat disimpulkan bahwa penerepan sistem manajemen mutu dapat berpengaruh terhadap pengembangan struktur organisasi.

- Prosentase kehadiran karyawan, ketepatan waktu tiba dikantor, ketepatan waktu meninggalkan kantor, kepuasan dalam melaksanakan pekerjaan, kepuasan atasan terhadap hasil pekerjaan, kepuasan pelanggan atas hasil pekerjaan dan hambatan - hambatan dalam pekerjaan

Tabel 7. Distribusi Frekuensi Jawaban Responden Untuk Variabel Budaya Kerja /Kinerja Karyawan

\begin{tabular}{|c|c|c|c|c|c|c|c|c|}
\hline \multirow{2}{*}{\begin{tabular}{|l|} 
Item Variabel (Y) \\
Penerapan SMM \\
\end{tabular}} & \multicolumn{8}{|c|}{ Jumlah Responden } \\
\hline & 1 & & 2 & & 3 & & 4 & \\
\hline Kinerja Karyawan & $\mathrm{F}$ & $\%$ & $\mathrm{~F}$ & $\%$ & $\mathrm{~F}$ & $\%$ & $\mathrm{~F}$ & $\%$ \\
\hline Y1 & - & - & 1 & 2,5 & 30 & 75 & 9 & 22,5 \\
\hline $\mathrm{Y} 2$ & - & - & 2 & 5 & 25 & 62,5 & 13 & 32,5 \\
\hline $\mathrm{Y3}$ & - & - & 3 & 7,5 & 28 & 70 & 9 & 22,5 \\
\hline Y4 & - & - & - & - & 26 & 65 & 14 & 35 \\
\hline $\mathrm{Y5}$ & - & - & 1 & 2,5 & 24 & 60 & 15 & 37,5 \\
\hline Y6 & - & - & 2 & 5 & 30 & 75 & 8 & 20 \\
\hline $\mathrm{Y7}$ & - & - & 1 & 2,5 & 27 & 62,5 & 12 & 30 \\
\hline
\end{tabular}


Pada item pertama (Y1.1) pada variable penerapan sistem manajemen mutu ISO 9001:2008 pada proses akademik untuk instrument kinerja karyawan yang menyatakan kurang berpengaruh sebanyak 2,5\%, yang menyatakan berpengaruh $9 \%$ dan yang menyatakan sangat berpengaruh sebanyak $22,5 \%$. Pada item kedua dengan variabel yang sama yang menyatakan kurang berpengaruh sebanyak 5\%, yang menyatakan berpengaruh sebanyak $62,5 \%$ dan yang menyatakan sangat berpengaruh sebanyak $32,5 \%$, pada item ketiga untuk variabel yang sama yang menyatakan kurang berpengaruh sebanyak $7,5 \%$, yang menyatakan berpengaruh sebanyak $70 \%$ dan yang menyatakan sangat berpengaruh sebanyak 22,5\%

Pengujian terhadap hipotesis yang diajukan dalam penelitian ini menggunakan analisis regresi berganda bertujuan untuk mengetahui besarnya pengaruh penerapanan sistem manajemen mutu ISO 9001:2008 untuk klausul 3.2 ; klausul 6.2 dan klausul 6.4 terhadap budaya kerja karyawan atau kinerja pegawai yang terlibat dalam proses utama yaitu proses akademik atau variabel Sumber Daya Manusia (X1), iklim organisasi (X2), dan struktur organisasi (X3) terhadap Kinerja Pegawai (Y). Nilai koefesien korelasi berganda antara $1 \leq \mathrm{R} \leq+1$, dimana nilai koefesien korelasi mempunyai arti sebagai berikut jika $\mathrm{R}=-1$ menunjukan bahwa ada korelasi negative sempurna antara seluruh variabel bebas terhadap variabel terikat, jika $\mathrm{R}=0$ maka tidak ada korelasi antara variabel bebas terhadap variabel terikat sedangkan jika $\mathrm{R}=+1$ menunjukan bahwa ada korelasi positif sempurna antara seluruh variabel bebas terhadap variabel terikat.

\begin{tabular}{|c|c|c|c|c|c|}
\hline Variabel & $\begin{array}{l}\text { Koefesien } \\
\text { Regresi (b) }\end{array}$ & Standart Error & T-hitung & Sig & Keterangan \\
\hline $\mathrm{X} 1$ & 0.330 & 0.091 & 4.038 & 0.000 & Signifikan \\
\hline $\mathrm{X} 2$ & 0.159 & 0.076 & 2.279 & 0.029 & Signifikan \\
\hline $\mathrm{X} 3$ & 0.547 & 0.092 & 6.104 & 0.000 & Signifikan \\
\hline \multicolumn{3}{|c|}{ R (Multiple R) } & \multicolumn{3}{|l|}{$=0,958$} \\
\hline \multicolumn{3}{|l|}{ R Square } & \multicolumn{3}{|l|}{$=0,918$} \\
\hline \multicolumn{3}{|c|}{ R Square (Adjusted) } & \multicolumn{3}{|l|}{$=0,911$} \\
\hline \multicolumn{3}{|c|}{ F hitung } & \multicolumn{3}{|l|}{$=133.598$} \\
\hline \multicolumn{3}{|l|}{ F tabel } & \multicolumn{3}{|c|}{$\begin{array}{l}=(\mathrm{df} \text { regresi }, \mathrm{df} \text { residual }) \\
=(3,36)=\mathbf{2 , 8 6 6}\end{array}$} \\
\hline \multicolumn{3}{|l|}{ Sign. F } & \multicolumn{3}{|l|}{$=0,000$} \\
\hline \multicolumn{3}{|l|}{$t$ tabel } & \multicolumn{3}{|c|}{$=(0,05 / 2,36)=2.028$} \\
\hline \multicolumn{3}{|l|}{$\alpha$} & \multicolumn{3}{|c|}{$=0,05$. } \\
\hline
\end{tabular}

Pada tabel diataa menunjukkan bahwa variabel-variabel yang mempengaruhi budaya kerja karyawan atau kinerja pegawai adalah semua variabel independen hal ini dikarenakan variabel tersebut memiliki nilai signifikan (Sig) kurang dari $\alpha=0,05$ dengan model regresi yang diperoleh

$$
\mathrm{Y}=0,330 \mathrm{X} 1+0,159 \mathrm{X} 2+0,547 \mathrm{X} 3
$$

Variabel Sumber Daya Manusia (X1) Koefisien regresi X1 menunjukkan tanda positif, yang berarti hubungan antara Sumber Daya Manusia (X1) dan Kinerja Pegawai (Y) berbanding lurus. Hal ini dapat diartikan bahwa semakin baik kompetensi, pelaksanaan pelatihan, dan kesadaran pegawai, maka kinerja pegawai akan meningkat. Variabel iklim organisasi atau ligkungan kerja (X2) menunjukkan tanda positif, yang berarti hubungan antara iklim organisasi atau lingkungan kerja (X2) dan Kinerja Pegawai (Y) berbanding lurus. Hal ini dapat diartikan bahwa semakin baik iklim organisasi atau lingkungan kerja, maka kinerja pegawai akan meningkat. Variabel Struktur Organisasi (X3) Koefisien regresi X3 menunjukkan tanda positif, yang berarti hubungan antara Struktur Organisasi (X3) dan Kinerja Pegawai (Y) berbanding lurus. Hal ini dapat diartikan bahwa semakin baik struktur organisasi maka kinerja pegawai akan meningkat.

Pengujian model regresi secara parsial (Uji t) digunakan untuk mengetahui pengaruh dari masing masing variabel independen (bebas) secara parsial (individu) terhadap variabel dependen (terikat) Rumusan hipotesis:

$$
\text { Ho : b1, b2, b3 = 0, }
$$


Secara parsial tidak terdapat pengaruh yang signifikan dari implementasi sistem manajemen mutu ISO 9001:2008,(X1) klausul 3,2 untuk struktur organisasi, klausul 6.2 untuk Sumber Daya Manusia, dan klausul 6.4 untuk iklim organisasi terhadap budaya kerja karyawan atau kinerja pegawai $(\mathrm{Y})$.

$$
\mathrm{Ha}: \mathrm{b} 1, \mathrm{~b} 2, \mathrm{~b} 3 \neq 0 \text {, }
$$

Secara parsial terdapat pengaruh yang signifikan ari implementasi sistem manajemen mutu ISO 9001:2008,(X1) klausul 3,2 untuk struktur organisasi, klausul 6.2 untuk Sumber Daya Manusia, dan klausul 6.4 untuk iklim organisasi terhadap budaya kerja karyawan atau kinerja pegawai (Y).

Uji $t$ dilakukan dengan membandingkan nilai thitung dengan ttabel. Variabel independen dikatakan berpengaruh signifikan jika thitung $>$ ttabel, atau Sig. (p) $<0,05$, maka Ho akan ditolak sebalikanya jika thitung $<$ ttabel, maka Ho akan diterima Perbandingan thitung dan ttabel masing-masing variabel bebas dapat dilihat pada tabel berikut

Tabel 9. Perbandingan thitung dan ttabel

\begin{tabular}{lllll}
\hline Variabel & thitung & ttabel & Sig & Keterangan \\
\hline Sumber Daya Manusia $(X 1)$ & 4,038 & 2,866 & 0,000 & Signifikan \\
\hline Iklim Organisasi /Lingkungan Kerja $(X 2)$ & 2,279 & 2,866 & 0,029 & Signifikan \\
\hline Struktur Organisasi $(X 3)$ & 6,104 & 2,866 & 0,000 & Signifikan \\
\hline
\end{tabular}

Dari tabel tersebut dapat disimpulkan bahwa variabel sumber daya manusia (X1) ,Variabel iklim organisasi atau lingkungan kerja (X2), dan variabel struktur organisasi (X3) berpengaruh signifikan terhadap variabel budaya kerja karyawan atau kinerja pegawai (Y) sehingga didapatkan keputusan bahwa masing-masing variabel menolak $\mathrm{H} 0$ dan menerima H1. Maka, hipotesis pertama dapat dinyatakan terbukti kebenarannya.

Hasil penelitian menunjukkan bahwa penerapan ISO 9001:2008 khususnya klausul 6.2 yaitu Sumber Daya Manusia yang meliputi Kompetensi, Pelatihan, dan pengembangan karir karyawan serta insfrastruktur kerja, dan klausul 6.4 tentang iklim organisasi atau lingkungan kerja dan klausul 3.2 tentang struktur organisasi berpengaruh signifikan terhadap budaya kerja karyawan atau kinerja pegawai khususnya pada proses akademik di Sekolah Tinggi Manajemen Informatika dan Teknik Komputer (STMIK) STIKOM Bali. Hal ini sesuai dengan pernyataan dari Prabowo (2009:121) bahwa dengan adanya kepedulian/kesadaran terhadap pekerjaan, secara psikologis akan mendorong semangat kerja pegawai. Semangat kerja inilah yang akan meningkatkan produktivitas. Selain itu dengan lingkungan kerja atau iklim organisasi yang kondusif dan komunikatif serta melaksanakan perbaikan secara berkesinambungan atau continous improvement melalui perbaikan kualitas yang mendasar diperlukan infrastuktur guna menunjang pengembangan organisasi kedepan

\section{KESIMPULAN}

Berdasarkan hasil analisa dan pembahasan tentang pengaruh penerapan sistem manajemen mutu ISO 9001:2008 pada proses akademik menggunakan klausul 3.2 tentang struktur organisasai (X3) meliputi pembagian tugas dan tanggung jawab, jaminan pengembangan karir karyawan serta hubungan dan komunikasi karyawan, klausul 6.2 tentang sumber daya manusia (X1) meliputi kompetensi, keahlian, pelatihan dan pendidikan serta kesadaran karyawan, klausul 6.4 tentang iklim organisasi atau lingkungan kerja (X2) yang meliputi hubungan dan komunikasi antara karyawan, dan atasan terhadap budaya kerja karyawan atau kinerja pegawai (Y) pada Sekolah Tinggi Manajemen Informatika dan Teknik Komputer (STMIK) STIKOM Bali. Dapat disimpulkan bahwa secara parsial dan simultan variabel - variabel pada penerapan sistem manajemen mutu ISO 9001:2008 berpengaruh positif dan signifikan terhadap budaya kerja karyawan di Sekolah Tinggi Manajemen Informatika dan Teknik Komputer (STMIK) STIKOM Bali dengan nilai thitung untuk variabel X1 sebesar 4.038 dan X2 sebesar 2.279 serta X3 sebesar 6.104 lebih besar dari nilai ttabel. Variabel yang 
memiliki pengaruh paling dominan terhadap budaya kerja karyawan adalah variabel X3 yaitu struktur organisasi dengan nilai Standardized Koefisien paling besar yaitu 6.104

$\mathrm{Hal}$ - hal yang disarankan berdasarkan hasil penelitian dan penarikan kesimpulan yang telah dilakukan di Sekolah Tinggi Manajemen Informatika dan Teknik Komputer (STMIK) STIKOM Bali mempertimbangkan cukup signifikannya penerapan sistem manajemen mutu ISO 9001:2008 pada proses akademik terhadap budaya kerja karyawan atau kinerja pegawai yang menjalankan proses tersebut maka Sekolah Tinggi Manajemen Informatika dan Teknik Komputer (STMIK) STIKOM Bali dapat mempertahankan sertifikasi ISO 9001:2008 yang telah diperoleh dengan meningkatkan kompetensi dan pemahaman karyawan tentang proses yang bermutu atau berkualitas, karena dengan proses yang bermutu maka output dari lulusan yang dihasilkan dari Sekolah Tinggi Manajemen Informatika dan Teknik Komputer (STMIK) STIKOM Bali bisa dijamin mutu dan kualitasnya serta tetap menjaga iklim organisasi atau lingkungan kerja yang kondusif dan komunikatif sehingga produktivitas karyawan dapat dioptimalkan

\section{SARAN}

Diharapkan penelitian yang akan datang lebih menyempurnakan penelitian ini, antara lain; memperluas responden dan data penelitian yang digunakan; memperbaiki atau menggunakan metode lain; mengembangkan model penelititan pengaruh timbal balik atau dengan menambahkan variabel lain, misalnya kinerja individu atau kinerja organisasi.

\section{UCAPAN TERIMA KASIH}

Penulis mengucapkan terima kasih kepada STMIK STIKOM Bali yang telah memberi dukungan financial terhadap penelitian ini.

\section{DAFTAR PUSTAKA}

[1] Connelly, C.E. and Kelloway, E.K. (2003). Predictors of Employees, Preceptions of Knowledge Sharing Culture, Leadership \& Organization Development Journal, 24(5), 294-301.

[2] Mei Feng,Mile terziovski and danny Samson, 2006, Relationshiop of ISO 9001:200 quality sistem cerfication with operational and business performance, WWW. Emeraldinsight.com.

[3] Standar Nasional Indonesia ISO 9001:2008. (2008) Sistem Manajemen Mutu Persyaratan. Parantapa. Management System Consulting

[4] Dorothy, G D. 2008. On quality in Education. Quality assurance in Education, Bradford: 2008, Vol. 16, Iss 3, p. 255.

[5] Setiawan,W, 2006, Pengaruh Penerapan Total Quality Management (TQM) terhadap Budaya Kualitas, Tesis, Program Pasca Sarjana, Universitas Brawijaya, Malang.

[6] Robbins, S.P. 2003. Organizational Behavior, Tenth Edition, Singapore: Prentice Hall.

[7] Arikunto, Soegiyono. (2007), Prosedur Penelitian Suatu Pendekatan Praktik, Jakarta ; Rineka Cipta.

[8] P. Listyo, S. 2008. Penjaminan Mutu dengan Sistem Manajemen ISO 9001-2000 di Perguruan Tinggi (Studi Multi Situs pada STIE Malang Kucecwara Malang dan Universitas NarotamaSurabaya). Disertasi. Malang: Universitas Negeri Malang. 